\title{
Hybridization in Selected Species and Genera of Diaptomid Copepods in China
}

\author{
Hui-Ming Li ${ }^{1,2}$, Ping Liu ${ }^{1}$, Xiao-Li Zhang ${ }^{1}$, Henri J. Dumont ${ }^{1,3}$ and Bo-Ping Han ${ }^{1, *}$ \\ 1 Institute of Hydrobiology, Jinan University, Guangzhou 510632, China; lihuiminghao@163.com (H.-M.L.); \\ liuping329098@163.com (P.L.); gzzx189@163.com (X.-L.Z.); Henri.Dumont@UGent.be (H.J.D.) \\ 2 College of Animal Science and Technology, Guangdong Polytechnic of Science and Trade, \\ International School Alliance of China, Guangzhou 510430, China \\ 3 Department of Biology, Ghent University, B-9000 Ghent, Belgium \\ * Correspondence: tbphan@jnu.edu.cn; Tel.: +86-020-38374600
}

Citation: Li, H.-M.; Liu, P.;

Zhang, X.-L.; Dumont, H.J.; Han, B.-P. Hybridization in Selected Species and Genera of Diaptomid Copepods in China. Water 2021, 13, 1181.

https://doi.org/10.3390/w13091181

Academic Editor: Arantza Iriarte

Received: 29 March 2021

Accepted: 20 April 2021

Published: 24 April 2021

Publisher's Note: MDPI stays neutral with regard to jurisdictional claims in published maps and institutional affiliations.

Copyright: (c) 2021 by the authors. Licensee MDPI, Basel, Switzerland. This article is an open access article distributed under the terms and conditions of the Creative Commons Attribution (CC BY) license (https:/ / creativecommons.org/licenses/by/ $4.0 /)$.

\begin{abstract}
To better understand the fauna of freshwater calanoid copepods of China, including the occurrence of intra- and intergeneric hybridization, we studied five species, distributed across the whole of China or in South China. We sequenced a mitochondrial (COI) and the nuclear ribosome $18 \mathrm{~S}$ operon (ITS) to reconstruct the phylogenetic trees by using a Bayesian and maximum likelihood (ML) approach with 161 individuals. The phylogeny tree revealed five clades and two geographically separated subclades in both S. ferus and P. tunguidus. We found, for the first time, that the hybrid specimens occurred in Diaptomidae, but low hybridization suggested effective barriers to hybridization and introgression. One hypothesis, that hybridization is recent and was initiated by invasions via canals built between the Yangtze and Pearl rivers c. 2000 years ago, is not supported by K2P genetic distances of the order of $20 \%$. Furthermore, COI analysis of different populations of $S$. ferus and P. tunguidus revealed two geographical clades in each species, with genetic distances commensurate with cryptic speciation. Both clades occupy subranges maintained without visible barriers to mixis.
\end{abstract}

Keywords: hybridization; molecular phylogeny; distribution; China; Neodiaptomus schmackeri; Phyllodiaptomus tunguidus; Sinodiaptomus sarsi; Sinodiaptomus ferus; Sinodiaptomus cavernicolax

\section{Introduction}

Formation of new species or merging of species by hybridization are interesting phenomena [1,2]. In freshwater Zooplankton, natural hybridization is common in the Cladocera [3-5], while Parent et al. (2012) found hybrids between Calanus finmarchicus and C. glacialis (Copepoda, Calanoida) in the Arctic and Northwest Atlantic [1]. In freshwater, the family Diaptomidae is the dominant taxon of the calanoida. Its taxonomy, both at the genus and the species level, relies heavily on the morphology of the fifth thoracic limb (P5) in males [6,7]. Historically, hybrid status of specimens was inferred from morphological analysis and ecological context, for example, in specimens morphologically intermediate and found in the zone of contact between the parental species [8]. However, for zooplankton species, it may be hard to find intermediacy in tiny characters. In fact, it should be shown that putative hybrids have genetic information of the two parental species. Hybridization has recently been suggested, using appropriate molecular techniques, between subspecies of Eodiaptomus endemic to the Malili lakes of Sulawesi [9].

The internal transcribed spacers (ITS) of the $18 \mathrm{~S}$ nuclear ribosomal DNA have been considered a useful molecular marker for hybrids [10,11]. Mitochondrial DNA is a circular molecule, with parental inheritance, a rapid evolutionary rate, and a large number of copies. It has been widely used for analyses of metazoan phylogenetic relationships at various taxonomic levels [12-15]. 
The freshwater Diaptomidae of China comprise 16 genera, with about 50 species [16]. Diaptomidae tend to have restricted ranges that may encompass several river basins, a single river basin, or part of a river basin. One of the species discussed here, Sinodiaptomus cavernicolax, is even restricted to a short underground river in Longyan, a cave which is part of the Star Lakes complex of Zhaoqing city, Guangdong province. Sinodiaptomus ferus is found in the Star lakes and in some reservoirs in the same general area. It also penetrates Longyan cave and meets S. cavernicolax there [17]. Females of the two can only be distinguished by body size. Sinodiaptomus sarsi, a third Chinese species of the genus, is widespread over China but with limited penetration in the west. Phyllodiaptomus tunguidus is widely distributed in the Yangtze but especially the Pearl River basin, including Star Lakes, where it is syntopic with the two aforementioned Sinodiaptomus species but has never been recorded in the cave. Neodiaptomus schmackeri also often coexists with P. tunguidus in South China. Coexistence of species and genera makes it theoretically possible for hybridization to occur. To evaluate this expectation, we used a combination of mitochondrial and nuclear DNA markers.

\section{Materials and Methods}

Thirteen sites were sampled from 6 provinces in China between 2011 and 2016 (Figure 1 and Table 1). Special attention was paid to Star Lakes $\left(23^{\circ} 6^{\prime} \mathrm{N} 112^{\circ} 23^{\prime}\right.$, Zhaoqing City, China), a complex composed of five shallow lakes (Bohai, Zhongxin, Qinglian, Fairy and Li). Longyan cave contains a shallow lake, a few hundreds of meters long and ending at the entrance of the cave. The distance between lake $\mathrm{Li}$ and the cave is not more than $10 \mathrm{~m}$ [17]. Five samplings in Star Lakes were carried out: in November 2011, July and November 2012, and again in October and November 2013, and May 2015. Zooplankton was collected with a plankton net of $120 \mu \mathrm{m}$ mesh size, towed from the bottom to the surface. All samples were preserved in ethanol $95 \%$ at $4{ }^{\circ} \mathrm{C}$.

We studied the Internal Transcribed Spacers (ITS) and the cytochrome c oxidase subunit I barcoding fragment (COI) according to the DNA extraction HOTSHOT technique [18]. We also downloaded four COI sequences of S. sarsi from GenBank, numbers AB699197.1, AB454129.1, AB454128.1, KU720101.1 and KR048945.1.

Complete ITS sequences (including ITS1, 5.8SrRNA and ITS2) of 151 specimens were amplified from total genomic DNA using polymerase chain reaction (PCR). Primers used were F2F (AGCAAAAGTCGTAACAAGGT) and V2R (TTTCACTCGCCGTTACTAAGGGAATC). The PCR conditions for amplification were: 35 cycles set at $30 \mathrm{~s}$ at $95{ }^{\circ} \mathrm{C}$ (denaturation), $30 \mathrm{~s}$ at $54{ }^{\circ} \mathrm{C}$ (annealing), and $60 \mathrm{~s}$ at $72{ }^{\circ} \mathrm{C}$ (extension), followed by $7 \mathrm{~min}$ at $72{ }^{\circ} \mathrm{C}$ (final-extension). For the cocktail, each $30 \mu \mathrm{L}$ consisted of $19.5 \mu \mathrm{L}$ dd $\mathrm{H}_{2} \mathrm{O}, 3 \mu \mathrm{L}$ PCR buffer, $1.2 \mu \mathrm{L}$ dNTP, $0.5 \mu \mathrm{L}$ of each primer, $5 \mu \mathrm{L}$ of DNA template and $0.3 \mu \mathrm{L}$ of Taq DNA polymerase (TaKaRa Taq ${ }^{\mathrm{TM}}$ Hot Star Version, Qiagen, Hilden, Germany) [19]. The COI sequences of 159 specimens were amplified. Primers used were ZplankF1 (TGTAAAACGACGGCCAGTTCTASWAATCATAARGATATTGG) and ZplankR1 (CAGGAAACAGCTATGACTTCAGGRTGRCCRAARAATCA) [20], as well as M13F (TGTAAACGACGGCCAGT) and M13R (CAGGAAACAGCTATGAC). The PCR conditions of COI for amplification were: 34 cycles set at $30 \mathrm{~s}$ at $98^{\circ} \mathrm{C}$ (denaturation), $30 \mathrm{~s}$ at $51{ }^{\circ} \mathrm{C}$ (annealing) and $60 \mathrm{~s}$ at $68^{\circ} \mathrm{C}$ (extension), followed by $5 \mathrm{~min}$ at $68^{\circ} \mathrm{C}$ (final-extension) on a 2720 Thermal Cycler (Applied Biosystems, Foster City, CA, USA). For the cocktail, each $30 \mu \mathrm{L}$ consisted of $4.9 \mu \mathrm{L}$ dd $\mathrm{H}_{2} \mathrm{O}, 15 \mu \mathrm{L} 2 \times$ PCR buffer, $0.8 \mu \mathrm{L}$ solution of each primer, $8 \mu \mathrm{L}$ of DNA template, and $0.5 \mu \mathrm{L}$ of MightyAmp DNA Polymerase (TaKaRa Taq ${ }^{\mathrm{TM}}$ Ver.2). PCR products were sequenced on an ABI 3130XL automatic sequencer. 
The authenticity of COI and ITS sequences were verified by a BLAST search in GenBank. The sequences were edited in Mega 7.0 (Institute for Genomics and Evolutionary Medicine, Temple University, USA) and Finch TV 1.5.0 (Geospiza Research Team, USA). The total length of the sequence segments after alignment were $555 \mathrm{bp}$ for COI and $652 \mathrm{bp}$ for ITS. We used Acanthodiaptomus pacificus as the outgroup species.

We used MRMODELTEST v.2.3 (Evolutionary Biology Centre, Uppsala University, Sweden) [21] to select the best-fit model of nucleotide substitution under the Akaike information criterion (AIC) [22]. Analyses were performed under Maximum likelihood (ML) and Bayesian inference. Maximum likelihood analysis was performed in PAUP* 4.0 beta 10 (Natural HistorySuvey, Champagne Urbana) [23], Bayesian analysis was performed using MRBAYES v3.1.2 (University of Rochester, Rochester, USA) [24,25]. Majority rule consensus trees were constructed after discarding a burn-in of 500 and displayed with FigTree v1.4.2 (Figtree HR Consultancy, The Hague, Netherlands). Genetic distances between COI sequences were calculated using the Kimura two-parameter (K2P) model in MEGA 7.0 [26].

Table 1. The summary of thirteen sampling locations in this investigation.

\begin{tabular}{|c|c|c|c|c|}
\hline Species & Code & Province & City & Site \\
\hline \multirow{7}{*}{$\begin{array}{l}\text { Neodiaptomus } \\
\text { schmackeri }\end{array}$} & China & Guangdong (GD) & Qingyuan & Feilaixia Reservoir \\
\hline & China & Guangdong (GD) & Kaiping & Dashahe Reservoir \\
\hline & China & Hubei (HB) & Chibi & Lushui lake \\
\hline & China & Yunnan (YN) & Kunming & Small pond \\
\hline & China & Yunnan (YN) & Kunming & Sanwan \\
\hline & China & Hainan (HN) & Danzhou & Songtao Reservoir \\
\hline & China & Heilongjiang (HLJ) & Haerbin & Hanxiao road \\
\hline \multirow{10}{*}{$\begin{array}{l}\text { Phyllodiaptomus } \\
\text { tunguidus }\end{array}$} & China & Yunnan $(\mathrm{YN})$ & Lijiang & Chahe \\
\hline & China & Guangxi (GX) & Baise & Zhexian river \\
\hline & China & Guangdong (GD) & Shaoguan & Tiantangshan \\
\hline & China & Guangdong (GD) & Conghua & Lixihe Resrevoir \\
\hline & China & Guangdong (GD) & Maoming & Luokeng Reservoir \\
\hline & China & Guangdong (GD) & Zhaoqing & Star Lakes \\
\hline & China & Guangdong (GD) & Zhuhai & Zhuyin Reservoir \\
\hline & China & Guangxi (GX) & Baise & Yangxu \\
\hline & China & Yunnan (YN) & Kunming & Xiaozhulong \\
\hline & China & Yunnan (YN) & Kunming & Sanwan \\
\hline \multirow{2}{*}{$\begin{array}{l}\text { Sinodiaptomus } \\
\text { ferus }\end{array}$} & China & Guangdong (GD) & Zhaoqing & Star Lakes \\
\hline & China & Guangdong (GD) & zhuhai & Zhuyin Reservoir \\
\hline $\begin{array}{l}\text { Sinodiaptomus } \\
\text { cavernicolax }\end{array}$ & China & Guangdong (GD) & Zhaoqing & Star Lakes \\
\hline $\begin{array}{l}\text { Acanthodiaptomus } \\
\text { pacificus }\end{array}$ & China & Heilongjiang (HLJ) & Haerbin & Hanxiao road \\
\hline
\end{tabular}



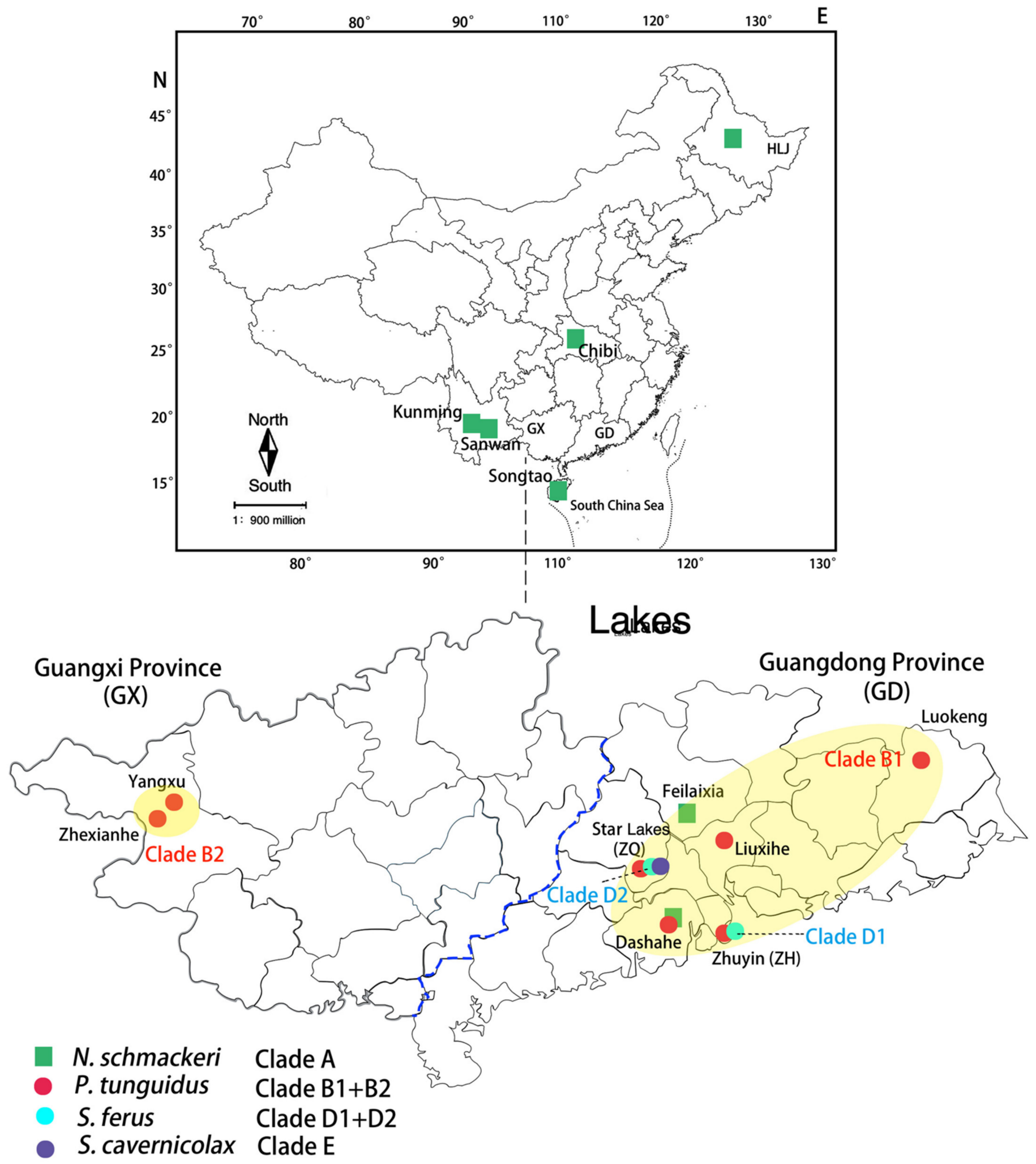

Figure 1. Thirteen sampling sites in China (Clade B1: P. tunguidus populations in Guangdong province (GD); Clade B2: P. tunguidus populations in Guangxi province (GX); Clade D1: S. ferus population in Zhuyin Reservoir, Zhuhai City, Guangdong province (ZH); Clade D2: S. ferus population in Star Lakes, Zhaoqing City, Guangdong province (ZQ)). 


\section{Results}

\subsection{Picking Hybrids from A Phylogenetic Tree}

We obtained 159 sequences of the COI gene fragment from 29, 54, 14, 5 and 44 individuals of N. schmackeri, P. tunguidus, S. sarsi, S. cavernicolax, S. ferus and 13 female specimens of Sinodiaptomus, respectively. We also obtained 151 sequences of ITS from 32, 49, 16, 22 and 21 individuals of N. schmackeri, P. tunguidus, S. sarsi, S. cavernicolax, S. ferus and 11 female specimens of Sinodiaptomus, respectively. The final sequences are available in NCBI under accession numbers MW820030-820084, MW819873-819901, MW820091-820159, and MN852697-852848.

The best-fitting model selected by MRMODELTEST 2.3 for the ITS dataset was of GTR $+\mathrm{G}$ with a relative AIC weight of 0.5110 and gamma distribution shape parameter 0.4060 . The best-fitting model for the COI dataset was GTR+I+G with a relative AIC weight of 0.7905 and gamma distribution shape parameter 0.7180 .

Bayesian inference and ML for both genes revealed the same five clades: N. schmackeri (A), P. tunguidus (B), S. sarsi (C), S. ferus (D), S. cavernicolax (E) (Figures 2 and 3). However, while in the COI tree, all specimens were recovered consistent with their morphological taxonomy (Figure 2A,B); in the ITS tree, some specimens end up in a "wrong" cluster (Figure 3A,B). The COI gene sequence always recovers the mother; if the ITS gene finds another species, the specimen in question is a hybrid. In Clade A of the ITS tree, No.9 S. ferus, for example, is a hybrid with $N$. schmackeri. Clade B contains one hybrid of $S . \times$ cavernicolax. Clade D contains two well-supported sublineages from Zhuyin reservoir, Zhuhai city (D1) and Star Lakes, Zhaoqing city (D2). In this clade, there are four putative hybrid specimens of $S . \times$ cavernicolax and one $P . \times$ tunguidus. Clade E contains three hybrids of $S . \times$ ferus. The COI tree reveals the same five well-supported main clades as the ITS tree. Five of ten hybrids form a clade of their own, with strong bootstrap support. In the COI tree, Clade $B$ and D both contain two well-supported sublineages from the Guangdong province population (B1) and Guangxi province population (B2), Zhuyin reservoir, Zhuhai city (D1) and Star Lakes, Zhaoqing city (D2), both in Guangdong province.

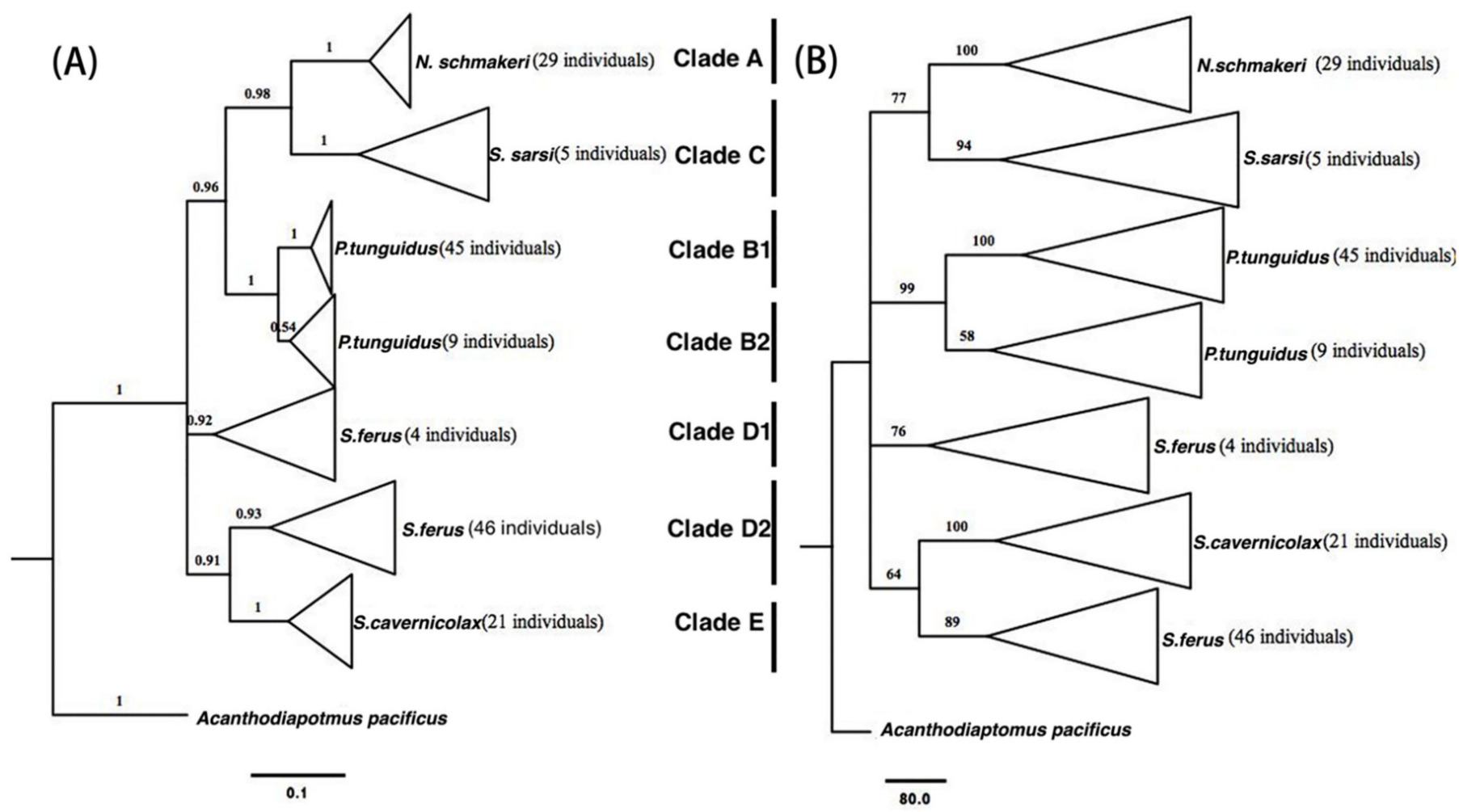

Figure 2. Phylogenetic tree of investigated species based on the sequences of their COI genes by Bayesian inference (A) and maximum likelihood method (B). 


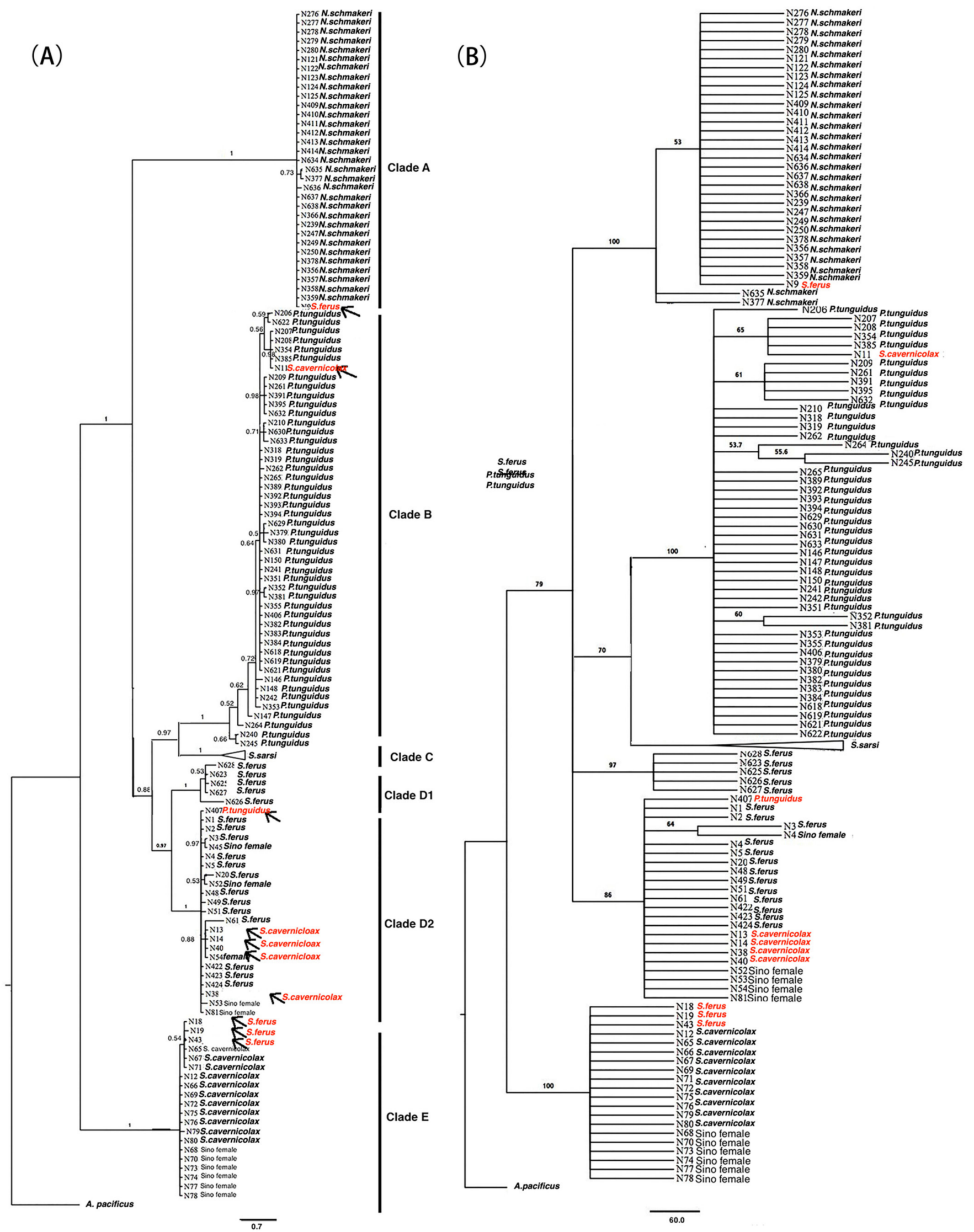

Figure 3. Phylogenetic tree of investigated species based on the sequences of their ITS genes by Bayesian inference (A) and maximum likelihood method (B). 


\subsection{COI Divergence}

The K2P pairwise distances derived from COI varied between $11 \%$ and $32.6 \%$. The highest distance was between clade C (S. sarsi) and clade D1 (S. ferus); the lowest was between clade B1 (P. tunguidus, Guangdong population) and B2 (Guangxi population). The second lowest genetic distance, $15.1 \%$, occurred between clade D2 (S. ferus) and clade E (S. cavernicolax). The distance between clades D1 and D2 reached $17.8 \%$ even though they were same morphospecies, higher than between clade E and D2, and also higher than the average intra-specific variation in Crustacea [27]. The average genetic distance between genera was $21.1 \%$; within genera it was $21.8 \%$ (Table 2).

Table 2. Range of maximum likelihood genetic distance (Kimura two-parameter model) between genera and lower-order clades, average \pm SD.

\begin{tabular}{llllllll}
\hline Clade & Species & A & B1 & B2 & E & D2 & D1 \\
\hline A & N. schmackeri & & & & & & \\
B1 & P. tunguidus GD & $0.23 \pm 0.025$ & & & & & \\
B2 & P. tunguidus GX & $0.242 \pm 0.026$ & $0.11 \pm 0.015$ & & & \\
E & S. cavernicolax & $0.23 \pm 0.023$ & $0.181 \pm 0.019$ & $0.206 \pm 0.022$ & & \\
D2 & S. ferus ZQ & $0.254 \pm 0.025$ & $0.179 \pm 0.019$ & $0.183 \pm 0.020$ & $0.151 \pm 0.016$ & & \\
D1 & S. ferus ZH & $0.243 \pm 0.023$ & $0.208 \pm 0.019$ & $0.202 \pm 0.020$ & $0.189 \pm 0.018$ & $0.178 \pm 0.017$ & \\
C & S. sarsi & $0.25 \pm 0.025$ & $0.266 \pm 0.027$ & $0.285 \pm 0.028$ & $0.303 \pm 0.029$ & $0.259 \pm 0.025$ & $0.326 \pm 0.028$ \\
\hline
\end{tabular}

\section{Discussion}

Hybrids in freshwater microcrustaceans are hard to identify by morphology, despite a high genetic divergence, which surely contributes to their apparent rarity. However, our results show that N. schmackeri, P. tunguidus, S. ferus and S. cavernicolax do hybridize, but hybridization rates are low, of an order of $5.4 \%$ between species and of $2.3 \%$ between genera. These results suggest the operation of rather effective pre- or post-mating barriers, and introgression is unlikely. At this stage, it is not possible to ascertain whether the hybrids are fertile or not.

S. cavernicolax is not, as its describers claimed (Shen and Tai, 1965), a true stygobiont, because it is not depigmented and has eyes. However, it has never been found outside Longyan cave. Hybrids between the congeners S. ferus and S. cavernicolax are therefore by necessity limited to the cave where the two coexist. $S$. ferus has a fairly restricted range but extends outside of the Star Lakes to parts of the west branch of the Pearl River.

$P$. tunguidus has, to date, never been found in the cave. The pond at the mouth of the cave is separated from Star Lakes by a narrow land bar. Currently, the levels of the lake as well as the cave river are controlled by pumps. Historically, floods of the Pearl River may have overflown, bringing lake and cave waters into direct contact. Dry episodes long enough to allow allopatric speciation to proceed are equally possible. That the two Sinodiaptomus share a common ancestor is beyond a reasonable doubt: they are morphologically extremely close and can only be distinguished structurally in males. Females can be distinguished by size: females of ferus are larger than of cavernicolax, but there is a 'grey zone' between them.

P. tunguidus is considered to be endemic to South China [28]. N. schmackeri is widely distributed in the whole of China except the cold, mountainous northwest [29]. Reproductive isolation is supposed to become stronger as genetic distance increases; therefore, barriers should become more hermetic as one moves from the species to the genus level. That is what we seemed to observe, with intergeneric hybrids an order of magnitude more rare than interspecies hybrids.

Could it be that the hybrids are an artifact of human disturbance of the river basins? China is reputed to have constructed some of the first and longest canals in the world, such as the Jing Hang Canal, the $1800 \mathrm{~km}$ long Grand Canal linking the Yellow River to the Yangtze basin, built between $486 \mathrm{BC}$ and $610 \mathrm{AD}$, and the Ling Qu canal in Guangxi Province, between the Yangtze and the Pearl River, built around 214 BC and which is $36 \mathrm{~km}$ 
long. In S. sarsi and the couple $S$ ferus-cavernicolax, another phenomenon seems to occur: here, the ranges are complementary, with possibly a hiatus between the two groups.

The species status of $S$. cavernicolax, finally, is not in doubt, and neither is its derivation from a common ancestor with $S$. ferus. Its genetic distance with $S$. ferus is consistent with a good species, and it appears to have evolved locally in Longyan cave.

\section{Conclusions}

In this study, we reconstructed the phylogenetic tree by Bayesian inference and Maximum likelihood method by using COI and ITS sequences from 161 specimens of N. schmackeri, P. tunguidus, S. sarsi, S. ferus and S. cavernicolax. The molecular analysis results provide evidence that there are certain cryptic species in Diaptomidae which have not yet been discovered, and we also find inter-specific and intra-specific hybridization in Diaptomidae with a low hybridization rate. This is the first time that hybrid Diaptomidae species have been found in freshwater.

Author Contributions: Conceptualization and investigation by H.J.D. and B.-P.H.; Draft preparation, review and editing by H.-M.L.; Molecular data analysis by X.-L.Z. and P.L. All authors have read and agreed to the published version of the manuscript.

Funding: This research was supported by the grant for NSF of China [No. 31670460].

Institutional Review Board Statement: This study did not require ethical approval.

Informed Consent Statement: Informed consent was obtained from all subjects involved in the study.

Data Availability Statement: Data available in a publicly accessible repository. The data presented in this study are openly available in GenBank, numbers AB699197.1, AB454129.1, AB454128.1, KU720101.1 and KR048945.1.

Acknowledgments: We greatly appreciate all colleagues from Jinan University, China, who participated in the numerous field trips that were part of this survey. Special thanks to Lei $\mathrm{Xu}$, Yang-Liang $\mathrm{Gu}$, Jie-Xiang Zhang for their invaluable help with field samples. Thanks to Andy Vierstraete from Gent University, Belgium, and Manuel Elias-Gutierrez from EI Colegio de La Frontera Sur (ECOSUR), Mexico, for their essential contribution to the molecular work.

Conflicts of Interest: The authors declare no conflict of interest.

\section{References}

1. Parent, G.J.; Plourde, S.; Turgeon, J. Natural hybridization between Calanus finmarchicus and C. glacialis (Copepoda) in the Arctic and Northwest Atlantic. Limnol. Oceanogr. 2012, 57, 1057-1066. [CrossRef]

2. Byrom, A.E.; Burns, C.W.; Wallis, G.P. Experimental hybridization of alpine and lowland forms of Boeckella dilatata, a calanoid copepod. Heredity 1993, 71, 508-515. [CrossRef]

3. Schwenk, K.; Spaak, P. Evolutionary and ecological consequences of interspecific hybridization in cladocerans. Experientia 1995, 51, 465-481. [CrossRef]

4. Wolf, H.G. Interspecific Hybridization between Daphnia Hyalina, D.galeata, and D.Cucullata and Seasonal Abundances of These Species and Their Hybrids. Hydrobiologia 1987, 145, 213-217. [CrossRef]

5. Spaak, P.; Rob Hoekstra, J. Life History Variation and the Coexistence of a Daphnia Hybrid With Its Parental Species. Ecology 1995, 76, 553-564. [CrossRef]

6. Reddy, Y.R. Copepoda: Calanoida: Diaptomus. In Guides to the Identification of the Microinvertebrates of the Continental Waters of the World; Dumont, H.J., Ed.; SPB Academic Publishing: Amsterdam, The Netherlands, 1994; p. 211.

7. Jaschnov, W.A. On the systematic Status of Calanus glacialis, Calanus finmarchicus and Calanus helgolandicus. Crustaceana 1972, 22, 279-284. [CrossRef]

8. Zhou, R.; Shi, S.; Wu, C. Molecular criteria for determining new hybrid species-an application to the Sonneratia hybrids. Mol. Phylogenet. Evol. 2005, 35, 595-601. [CrossRef]

9. Vaillant, J.J.; Bock, D.G.; Haffner, G.D.; Cristescu, M.E. Speciation patterns and processes in the zooplankton of the ancient lakes of Sulawesi Island, Indonesia. Ecol. Evol. 2013, 3, 3083-3094. [CrossRef] [PubMed]

10. Baldwin, B.G. Phylogenetic Uitlity of the Internal Transcribed Spacers of Nuclear Ribosomal DNA in Plant: An Example from the Compositae. Mol. Phylogenet. Evol. 1992, 1, 3-16. [CrossRef] 
11. Baldwin, B.G.; Sanderson, M.J.; Porter, J.M.; Wojciechowski, M.F.; Campbell, C.S.; Donoghue, M.J.; Porter, J.I.M.; Wojciechowski, F.; Campbell, S. The its Region of Nuclear Ribosomal DNA: A Valuable of Evidence on Angiosperm Phylogeny. Ann. Missouri Bot. Gard. 1995, 82, 247-277. [CrossRef]

12. Blanco-Bercial, L.; Bradford-Grieve, J.; Bucklin, A. Molecular phylogeny of the Calanoida (Crustacea: Copepoda). Mol. Phylogenet. Evol. 2011, 59, 103-113. [CrossRef]

13. Braga, E.; Zardoya, R.; Meyer, A.; Yen, J. Mitochondrial and nuclear rRNA based copepod phylogeny with emphasis on the Euchaetidae (Calanoida). Mar. Biol. 1999, 133, 79-90. [CrossRef]

14. Bucklin, A.; Frost, B.W.; Bradford-Grieve, J. Molecular systematic and phylogenetic assessment of 34 calanoid copepod species of the Calanidae and Clausocalanidae. Mar. Biol. 2003, 142, 333-343. [CrossRef]

15. Machida, R.J.; Miya, M.U.; Nishida, M.; Nishida, S. Large-scale gene rearrangements in the mitochondrial genomes of two calanoid copepods Eucalanus bungii and Neocalanus cristatus (Crustacea), with notes on new versatile primers for the srRNA and COI genes. Gene 2004, 332, 71-78. [CrossRef]

16. Li, H.; Dumont, H.J.; Han, B.P.; Lin, Q. Updated checklist and distribution of the diaptomid copepods (Copepoda, Calanoida, Diaptomidae) of China. Crustaceana 2018, 91, 335-352. [CrossRef]

17. Li, H.M.; Han, B.; Guo, F.; Dumont, H.J. Re-allocation of two south Chinese species of Argyrodiaptomus Brehm, 1933 to Sinodiaptomus Kiefer, 1932, and biogeography of the genus Sinodiaptomus (Copepoda, Calanoida, Diaptomidae). Crustaceana 2014, 87, 328-339. [CrossRef]

18. Montero-Pau, J.; Gómez, A.; Muñoz, J. Application of an inexpensive and high-throughput genomic DNA extraction method for the molecular ecology of zooplanktonic diapausing eggs. Limnol. Oceanogr. Methods 2008, 6, 218-222. [CrossRef]

19. Xu, L.; Han, B.-P.; Van Damme, K.; Vierstraete, A.; Vanfleteren, J.R.; Dumont, H.J. Biogeography and evolution of the Holarctic zooplankton genus Leptodora (Crustacea: Branchiopoda: Haplopoda). J. Biogeogr. 2011, 38, 359-370. [CrossRef]

20. Prosser, S.; Martínez-Arce, A.; Elías-Gutiérrez, M. A new set of primers for COI amplification from freshwater microcrustaceans Mol. Ecol. Resour. 2013, 13, 1151-1155. [CrossRef]

21. Nylander, A.A. MrModeltest, v2. Program Distributed by the Author. 2004. Available online: http://www.abc.se/nylander/ mrmodeltest2/mrmodeltest2.html (accessed on 5 May 2019).

22. Posada, D.; Crandall, K.A. MODELTEST: Testing the model of DNA substitution. Bioinformatics 1998, 14, 817-819. [CrossRef]

23. Swofford, D. PAUP*-Phylogenetic Analysis Using Par-Simony ( ${ }^{*}$ and Other Methods), Version 4.10b; Sinauer Associates, Inc.: Sunderland, MA, USA, 2003.

24. Huelsenbeck, J.P.; Ronquist, F. MRBAYES: Bayesian inference of phylogeny. Bioinformatics 2001, 17, 754-755. [CrossRef] [PubMed]

25. Huelsenbeck, J.P.; Ronquist, F.; Nielsen, R.; Bollback, J.P. Bayesian inference of phylogeny and its impact on evolutionary biology. Science 2001, 294, 2310-2314. [CrossRef] [PubMed]

26. Kumar, S.; Nei, M.; Dudley, J.; Tamura, K. MEGA: A biologist-centric software for evolutionary analysis of DNA and protein sequences. Brief. Bioinform. 2008, 9, 299-306. [CrossRef]

27. Costa, F.O.; de Waard, J.R.; Boutillier, J.; Ratnasingham, S.; Dooh, R.T.; Hajibabaei, M.; Hebert, P.D. Biological identifications through DNA barcodes: The case of the Crustacea. Can. J. Fish. Aquat. Sci. 2007, 64, 272-295. [CrossRef]

28. Dumont, H.J.; Reddy, Y.R. A reappraisal of the genus Phyllodiaptomus Kiefer, 1936, with the description of P. wellekensae n. sp. from India, and a redescription of P.tunguidus Shen \& Tai, 1964 from China (Copepoda, Calanoida). Hydrobiologia 1993, 263, 65-93.

29. Li, H.-M. Species Diversity, Phylogeny and Biogeography of Diaptomidae (Copepoda:Calanoida) in China; Jinan University: Guangzhou, China, 2017. 